\title{
The International Union of Social Studies of Malines and the Catholic Cultural Turn
}

\section{Drafting a Moral Code at the End of the Constantinian Era}

\author{
Dries Bosschaert \\ KU Leuven \\ dries.bosschaert@kuleuven.be
}

\begin{abstract}
The present article argues that the unexpected end of the Union de Malines' Code de morale culturelle, an international collaboration of prominent twentieth-century Catholic moral theologians, should be attributed to three shifts in Catholic Social Teaching, only the first two of which the Union de Malines managed to undergo: from scholastic hegemony to theological diversity, from social doctrine to personalism, and from a juridical style of writing to a humanistic one. Particularly this last shift, introduced by the Second Vatican Council, proved to be a too big a leap for the Union, understood as a 'little social tradition,' to take. The cultural turn, which the Union de Malines had in fact anticipated, proved by the end of the council to belong to the future.
\end{abstract}

\section{Keywords}

Union Internationale d'Etudes Sociales de Malines (Union de Malines) - Catholic Social Teaching - Theology of Culture - Gaudium et spes - Second Vatican Council

In 1961, the French Dominican Marie-Dominique Chenu announced in his programmatic La fin de l'ère Constantinienne the renewal of Western Christianity and its transformation into a global church, including the collapse of the classical doctrinal tradition of social Catholicism. ${ }^{1}$ For a long time this tradition

1 Marie-Dominique Chenu, "La fin de l'ère Constantinienne," in Un concile pour notre temps, ed. J.-P. Dubois-Dumée, et al. (Paris, 1961), 59-87. 
had given the impression to offer a monolithic body of principles, based on clear philosophical foundations and expressed in magisterial documents, on which Catholic civilization could be built as a 'third way' between capitalism and socialism. The new approach of the papal encyclicals Mater et magistra (1961) and Pacem in terris (1963) and even more so Vatican II's Pastoral Constitution Gaudium et spes (1965) seemed to affirm Chenu's observation. It was widely felt that the conciliar "pastoral shift" 2 had rendered the "Grand Tradition' of Catholic Social Doctrine obsolete and had installed a new approach to modernity on the part of the Catholic Church, an approach which legitimized the valid diversity of 'little social traditions. ${ }^{3}$ Yet some traditions were more apt to thrive in this new context than others. Though successful in the interbellum, the International Union of Social Studies of Malines (Union Internationale d'Etudes Sociales de Malines hereafter, Union de Malines) now faced a challenge in realizing its past core aims of studying social problems and actualizing the social doctrine of the Church in resolutions and moral codes: surveys of Catholic Social Doctrine on a certain topic. Although the Union's plan to draft a Code de morale culturelle already constituted a shift away from its previous alignment with the grand tradition of Rerum novarum, ${ }^{4}$ the project encountered challenges that arose from ecclesial and societal developments. Though practically complete by 1964, the Code de morale culturelle was never published, and the project came to an end in 1969 when the Union de Malines ceased to exist after the death of its secretary, the economist Giovanni Hoyois. Reflecting on the Union's demise, the historians De Maeyer and Van Molle concluded concerning the failure of the integration of new social themes and a global perspective that "without doubt the Union had become literally too old to do

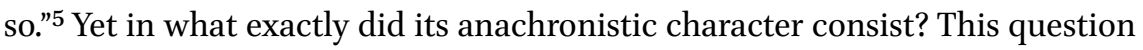
remains to be answered.

The present contribution argues that the answer to this question may be found in three shifts that the Union de Malines was bound to undertake if it was going to align itself anew with the Catholic Church's evolving grand tradition of

2 Identified as one of the key notions in conciliar hermeneutics by John W. O'Malley, "Vatican II: Did Anything Happen?," Theological Studies 67 (2006), 3-33.

3 For a discussion of this distinction between the 'Grand Tradition' of the encyclicals and magisterial texts and the 'little traditions' present in the labor movement, see Kees van Kersbergen, Social Capitalism: A Study of Christian Democracy and the Welfare State (London, 1995), 192204.

4 Jan De Maeyer and Leen Van Molle, "Les effets de Rerum Novarum en Belgique," in I tempi della Rerum Novarum, ed. Gabrielle De Rosa (Soveria Mannelli, 2003), 133-141.

5 "Sans doute l' Union était-elle devenue littéralement trop vieille pour cela," in De Maeyer and Van Molle, 'Les effets de Rerum Novarum en Belgique,' (see above, n. 4), 140. 
social teaching. First of all, we will see that after years of inactivity the Union de Malines had to work for the rejuvenation of its members in order to ensure its continuation and renew its own tradition. This process required the Union to undertake a shift away from the scholastic tradition towards integrating theological diversity. Secondly, the drafting of the Code de morale culturelle required the Union de Malines to undertake a shift away from its philosophical basis in the theory of natural law towards a more personalist approach. Thirdly, and unexpectedly, the drafters of the code had to deal with a major development in Catholic Social Teaching: the convocation of the Second Vatican Council in 1959, the plan, at the end of 1962, to devote an entire schema to the Church in the modern world, and the eventual inclusion of a chapter on culture in the Pastoral Constitution Gaudium et spes. All these events impinged on the redaction of the Code de morale culturelle and pushed the tensions between the grand and the little tradition to their limits. The conciliar pastoral shift from a juridical to a humanistic style of engagement proved to be particularly challenging for the Union de Malines to adopt.

Though the history of the Union de Malines has already been surveyed by its last secretary Giovanni Hoyois ${ }^{6}$ and by De Maeyer and Van Molle, these studies gave only limited attention to the post-Second World War developments and the final days of the Union. Yet as a well-established organization in this period, the Union de Malines presents us with an opportunity for a unique case-study that sheds light on the transformation of Catholic Social Teaching in the 196os, not from the point of view of the magisterial doctrinal tradition, but from one of the "many tongues" that had its own discourse in pre-conciliar times, one which also appealed in a forceful way to the Catholic Social Teaching that characterized ultramontane mass Catholicism. ${ }^{7}$ Despite the wide historiographical fields devoted to social movements such as the Catholic labor movement and Left Catholicism, or to theological currents such as ressourcement and the nouvelle théologie, ${ }^{8}$ the intellectual development of twentieth-century

6 Giovanni Hoyois, "L’Union de Malines," La Revue Nouvelle 4 (1946), 681-684; Giovanni Hoyois, "Les origines du 'Code social' de l'Union de Malines," in Album Professor Van Goethem (Antwerp, 1964), 577-605.

7 Staf Hellemans, "Is there a future for Catholic Social Teaching after the waning of Ultramontane Mass Catholicism," in Catholic Social Thought: Twilight or Renaissance?, ed. J.S. Boswell, Francis P. McHugh, and Johan Verstraeten [Bibliotheca Ephemeridum Theologicarum Lovaniensium, 157] (Leuven, 2000), 13-32, there 30.

8 The four fields mentioned are too broad to provide extensive bibliographies here, but good introductions can be found, respectively, in Paul Misner, Catholic Labor Movements in Europe: 1914-1965 (Washington, 2015); Gerd-Rainer Horn, The Spirit of Vatican II: Western European Progressive Catholicism in the Long Sixties (Oxford, 2015); Gabriel Flynn and Paul D. Murray, 
Catholic social traditions such as the Union de Malines has gone largely unstudied in comparison with, for instance, the Social Gospel movement in the U.S. ${ }^{9}$ By focusing on the drafting of this 196os code on culture and relating it to the drafting of Gaudium et spes, this article engages with the present-day theological debate about the conciliar treatment of culture. Critiquing the Pastoral Constitution's ambiguous use of the term 'culture, the Radical Orthodoxy theologian Tracey Rowland deplores the document's broad and shallow analysis of culture, specifically the absence of an underlying theology of culture and the "neglect of important pre-conciliar scholarship" on the matter. ${ }^{10}$ Leaving aside the impact of the Code de morale culturelle on the final form of the Pastoral Constitution, the present contribution nevertheless shows that the redactors of Gaudium et spes did appeal to pre-conciliar scholarship on culture, though it was scholarship from the discipline of moral theology rather than dogmatic theology. Bringing these two fields together will enable us to observe the interplay between the grand tradition and one of the little social traditions within Catholicism.

\section{The Union de Malines: From Scholastic Hegemony to Theological Diversity}

Five years after their last meeting in $1956,^{11}$ the members of the Union de Malines received a letter from their secretary that invited them to a new session and announced the need for their assistance in drafting a Code de morale culturelle. ${ }^{12}$ Given that some of its members had recently passed away and some

eds., Ressourcement: A Movement for Renewal in Twentieth-Century Catholic Theology (Oxford and New York, 2012); Jürgen Mettepenningen, Nouvelle théologie—New Theology: Inheritor of Modernism, Precursor of Vatican II (London and New York, 2010).

9 See, for example, the special section devoted to Social Gospel studies in Church History 84 (2015), 195-219. In a similar sense, reference can be made to the study Randall Balmer, " "An End to Unjust Inequality in the World": The Radical Tradition of Progressive Evangelicalism," Church History and Religious Culture 94 (2014), 505-530.

10 Tracey Rowlands, Culture and the Thomist Tradition After Vatican II, Radical Orthodoxy Series (London-New York, 2003), esp. 17-22.

11 Documents préparés à la session du 12-13 avril 1956, in Fonds Giovanni Hoyois 798. It was at this session of the Union de Malines that the project of the Code de Morale Culturelle was first launched. The Giovanni Hoyois collection (hereafter F-Hoyois) is kept at the Archives du Monde Catholique (ARCA), Maisons Belcoha, Sentier du Goria 6, Louvain-la-Neuve, Belgium.

F-Hoyois 765, Letter of G. Hoyois to the members of the UIE S, 29.12.196o. 
had become too old to attend the meetings, ${ }^{13}$ this invitation came at a decisive moment, a time to consider how to rejuvenate the organization. Such a possibility also raised questions about the organization's mission. From the start, the Union de Malines had understood itself as fulfilling the same mission as the Union de Fribourg, in a time when the social question had received new meaning, which therefore necessitated the development of a new social doctrine. The emphasis on a deeper understanding of the philosophical principles underlying these social questions was directly in line with the program set out by the original stakeholders of the Union de Malines, many of whom were located in the open neo-thomist milieu of the Leuven Higher Institute for Philosophy. ${ }^{14}$ Not without reason did the initiators, the Belgian minister Joris Helleputte and the president of the Semaines sociales de France ${ }^{15}$ Eugène Duthoit, ask Cardinal Désiré Mercier to take up the presidency of the Union de Malines. Subsequent secretaries, such as the professor of social theories Maurice Defourny and the professor of rural sociology Giovanni Hoyois, similarly guaranteed that the goals of the Union de Malines concerning the formulation of social theory kept up with the goals of neo-thomism as set out in Aeterni Patris, namely, to demonstrate, synthesize, and defend the faith.

Established on this Thomist basis, the moral codes that the Union de Malines produced exhibited two of the three methodological characteristics attributed to neo-thomism by the French historian Etienne Fouilloux. ${ }^{16}$ To start with, the medieval scholastic inspiration of neo-thomism, which after the modernist crisis gave rise to a manualist tradition, ${ }^{17}$ was also reflected in the pedagogical approach of the moral codes, which often adopted a question-and-answer format. Scholasticism's speculative nature, the second characteristic identified by Fouilloux, does not seem to have threatened the Union de Malines, since its focus on social issues and not merely philosophical and theological topics kept

13 See Compte rendu (1964), in F-Hoyois 8oo. Also illustrative in this regard are Hoyois's membership lists of 1953 and 1964, which indicate that almost half of the Union's approximately 60 members had passed away in the preceding decade. Finally, at the meeting of 1961, only seven of the 35 invited members were actually present. See Compte rendu (1961), in F-Hoyois 799 .

14 Roger Aubert, "Désiré Mercier et les débuts de l'Institut de Philosophie," Revue philosophique de Louvain 88 (1990), 147-167.

15 On the latter organization, see Jean-Dominique Durand, ed. Les semaines sociales de France: cent ans d'engagement social des catholiques français 1904-2004: actes du Colloque international d'histoire: 13-16 octobre 2004 [Pages d'histoire] (Paris, 2004).

16 Etienne Fouilloux, Une église en quête de liberté: La pensée catholique française entre modernisme et Vatican II (1914-1962), Anthropologiques (Paris, 1998).

17 Jared Wicks, "Theology, Manualist," in Dictionary of Fundamental Theology, ed. René Latourelle and R. Fisichella (New York, 1996), 1102-1105. 
the moral codes from adopting the metaphysical and rather abstract discourse of neo-thomism. The latter's deductive approach, which is the third characteristic, was by contrast very evident in the organization's moral codes, based as they were on Catholic Social Doctrine as previously defined in magisterial teaching. The reliance of the Union de Malines on the deductive method was, moreover, repeatedly highlighted in the introductions to the moral codes, as exemplified in the introduction to its code on politics:

Without engaging in theological work, the Union seeks to chart these paths in the light of the Church's teachings. It would like to make an effort towards integrating Catholic doctrine into a system of thought that can constitute a social philosophy. [...] Like the other Codes, this one is essentially based on moral speculation. [...] It consists in proposing [to political action], according to the norms of natural law, a set of reflections likely to mark a point of departure, both for the conception of a constitutional order and for the day-to-day government of the State. ${ }^{18}$

The mainly Belgian and French composition of the Union de Malines expanded over the years to an international cast of approximately 60 members, who met on a yearly basis to discuss and approve resolutions and moral codes. As the membership list of 1953 shows, however, the Belgian and French origins remained dominant. At that time, the organization was presided over by Cardinal Jozef Van Roey, and several important societal figures were members, among whom were the lawyer Fernand Van Goethem, the economist Fernand Baudhuin, the industrialist Léon Bekaert, the Catholic Workers' Union chaplain Antoon Brys, and the jurist Jean Dabin. From the French side, the presence of Stanislas de Lestapis and Gustave Desbuquois of the French Jesuit movement Action populaire was especially notable. This last organization, which aimed at promoting Catholic Social Doctrine in society through, for example, its publications and its Institut d'Etudes Sociales at the Institut catholique de Paris, was

18 'Sans faire œuvre théologique, l' Union cherche à tracer ces voies à la lumière des enseignements de l'Eglise. Elle voudrait faire effort vers une intégration de la doctrine catholique dans un système de pensée qui puisse constituer une philosophie sociale. [...] Comme les autres Codes, celui-ci se tient essentiellement sur le plan de la spéculation morale. [...] Elle consiste à lui [l' action politique] proposer, d' après les normes du droit naturel un ensemble de réflexions susceptibles de tracer une ligne de départ, tant pour la conception d'un ordre constitutionnel que pour le gouvernement journalier de l'Etat," in Union Internationale d'Etudes Sociales, Code de Morale Politique: Synthèse doctrinale (Bruxelles—Paris, 1957), 10. 
one of the major players in the French milieu of social traditions. ${ }^{19}$ In addition, Bruno de Solages, the rector of the Institut catholique de Toulouse and one of the prominent voices in the nouvelle théologie with strong links to the Jesuits of La Fourvière, figured among the members of the Union de Malines. The Belgian and French bloc, however, made up only half of the total membership, which was far more international, yet still mostly European, with significant Jesuit representation. The international members also included heavyweights of Catholic social thought. Among the German members, the professor of Social Sciences in Münster and later archbishop Joseph Höffner and the Jesuit Joseph Joos were known for their advisory role to Christian Democratic officials, and the Jesuit Oswald von Nell-Breuning was highly respected for his role in drafting Pius XI's 1931 social encyclical Quadragesimo anno. On the Italian side, there were some prominent names too, such as Pietro Pavan, who would become one of the advisors to whom Pope John XxiII would repeatedly turn when writing his social encyclicals Pacem in terris and Mater et magistra. Despite all these well-respected figures, the absence of women among them is especially significant when we take into account that by 1953 figures such as the British economist Barbara Ward Jackson, the Dutch House representative and later minister of Social Work Marga Klompé, or the Belgian senator Maria Baers had already made names for themselves in the field of social Catholicism.

Giovanni Hoyois made good use of the thematic specificities of the Code de morale culturelle to rejuvenate the membership of the Union de Malines after its standstill between 1953 and 1956. In the first instance, Hoyois still relied to a great extent on the traditional contacts of the Union de Malines, turning, for example, to the director of Action populaire Pierre Bigo. ${ }^{20}$ Although the author of the high-profile volume Marxisme et Humanisme could have been a drafter himself, ${ }^{21}$ he called on his fellow Jesuits instead. After an initial contact with Robert Seillon, Alfred de Soras would take the lead in the drafting from the side of the Action populaire. He would seek the advice of P. Bretaudeau from Pax Christi, but he would also appeal to other Jesuits, such as the young Michel de Certeau. ${ }^{22}$ In the Belgian context, Hoyois counted mostly on the

19 Paul Droulers, "L'action populaire et les semaines sociales de France, 1919-1939," Revue d'histoire de l'Eglise de France 179 (1981), 227-252; Etienne Fouilloux, "L'Action populaire au temps de la reconstruction 1946-1958," Chrétiens et Sociétés: XVIe-XXIe siècles 11 (2004), 49-6o; Joseph Joblin, "Le projet apostolique du christianisme social: L' Action populaire face à l' apostasie des masses," Gregorianum 93 (2012), 527-547.

$20 \quad$ For the correspondence between Hoyois and Bigo, see F-Hoyois 833 .

21 Pierre Bigo, Marxisme et Humanisme. Introduction à l'oeuvre économique de Karl Marx (Paris, 1953).

See Note on Michel de Certeau, s.d, in F-Hoyois 856 . 
progressive Christian milieu in evidence among disciples of the Leuven sociologist and founder of la cite chrétienne Jacques Leclercq, particularly André Molitor, ${ }^{23}$ and participants in the interdisciplinary study group Groupe de synthèse, such as Jean Vieujean, Charles Moeller, and Albert Dondeyne. ${ }^{24}$ Hoyois's reliance on this last group in particular enriched the Union de Malines with ideas about culture stemming from conversations between scientists, philosophers, and theologians. Hoyois also appealed to a number of international external experts. Over the years he started to rely more and more on the Jesuits: Edward Coffey, professor at the Gregorian University; François Russo, the ecclesial counselor for the Catholic presence at Unesco; Joseph Géraud, a medical doctor and priest; and Victor Heylen, a professor of moral theology at Louvain and national chaplain of the Christian Health Service. It should be noted that the last three were later proposed as new members of the Union de Malines, while Coffey already was. ${ }^{25}$ By the end of the redaction process, they had almost completely taken over the role that was originally filled by Action populaire. The introduction of these different groups into the work of the Union de Malines not only provided the organization with younger members, but also renewed it intellectually and methodologically. The previous focus on socioeconomic matters was subject to a cultural turn. Methodologically the neoscholastic dominance gave way to a phenomenological approach, much more common in the intellectual circles now joined to the Union de Malines. In sum, this organization devoted to the study of society and reliant on neo-scholastic tradition was now diversified by different cultural and theological currents.

The project to produce a Code de morale culturelle was thoroughly rooted in the past work of the Union de Malines, which regularly issued relevant presentations of Catholic Social Doctrine: shorter resolutions on concrete topics were regularly published, the last in 1966 on the moral aspects of strikes, ${ }^{26}$

23 Jean-Louis Jadoulle, Chrétiens modernes? L'engagement des intellectuels catholiques 'progressistes' belges de 1945 à 1958 à travers La revue nouvelle, La relève et l'édition belge de Témoignage chrétien [Bibliothèque de la Faculté de philosophie et lettres] (Louvain-laNeuve, 2003).

24 Luc Courtois, Françoise Hiraux, and Paul Servais, "Le groupe de synthèse de Louvain," in Les religions à l'école: Europe et Amérique du Nord: XIXe-XXIe siècles, ed. Jean-François Lalouette (Paris, 2011), 199-211.

25 It should be pointed out that Coffey was already a member of the Union de Malines.

26 Union Internationale d'Etudes Sociales, "La grève devant la conscience," Collectanea 
and more extensive codes were devoted to broader issues. This tradition was launched in the interbellum period with the publication of its Code social, a kind of social catechism containing the Union's conclusions on economic matters, and the Code de morale internationale, on international politics and societal organization. ${ }^{27}$ The latter document's introduction emphasized its dogmatic-philosophical character and adherence to doctrinal tradition. ${ }^{28}$ Constantly adapting to changing contexts and adhering to official Catholic Social Doctrine remained crucial. Hence the republication of both moral codes in the postwar context, integrating, for example, the ideas of internationalism, fueled by the foundation of the United Nations, and the teachings of Pope Pius XII on the topic. The Union de Malines' postwar moral codes similarly provided summaries and applications of catholic doctrine regarding the family and politics. ${ }^{29}$ The aim of these moral codes, to reestablish the philosophical principles underlying society, tied in with the aims of the French publishing house Spes, which had been founded by the Jesuits of Action populaire. ${ }^{30}$ The underlying conviction that it was important to philosophically capture the essentials of reality in clear a definition would, however, be obscured from the late 1950s onwards. ${ }^{31}$ Certainly during the redaction of the Code de Morale Culturelle, this tension was experienced as an urge to make the necessary move away from a classic natural-law and doctrinal perspective to a personalist approach. ${ }^{32}$

Mechliniensia $5^{1}$ (1966), 270-278. Also of note here is the 1931 bibliography of Catholic Social Teaching: Union Internationale d'Etudes Sociales, La hiérarchie catholique et le problème social depuis l'encyclique 'Rerum Novarum' 1891-1931: Répertoire bibliographique des documents emanés des souverains pontifes et de l'épiscopat (Paris, 1931).

27 Union Internationale d'Etudes Sociales, Code Social: Esquisse d'une synthèse sociale catholique (Paris, 1927); Union Internationale d'Etudes Sociales, Code de Morale Internationale (Paris, 1937).

28 Union Internationale d'Etudes Sociales, Code de Morale Internationale, 9.

29 Union internationale d'Etudes Sociales, Code Familial: Synthèse doctrinale (BruxellesParis, 1950).

30 On the mission of this publishing house, see Philippe Rocher, "Une reconquête éducative catholique par le livre: l'Action populaire et les éditions Spes (1922-196o)," in Education, religion, laïcité (xvie-xxe siècles). Continuités, tensions et ruptures dans la formation des élèves et des enseignants, ed. Jean-François Condette (Villeneuve-d'Ascq, 2010), 479-507.

31 As noted in the introduction to its 1957 code, Hoyois pointed out the following: "Des notions, des définitions qui avaient pour objet les réalités essentielles de la vie politique, que le droit public considérait comme acquises et que les moralistes lui empruntaient sans les discuter, sont aujourd'hui singulièrement obscurcies," in Union Internationale d'Etudes Sociales, Code de Morale Politique: Synthèse doctrinale, 16.

32 This development of moral theology in the twentieth century was described at length in E. Martin Meunier, Le pari personnaliste: Modernité et catholicisme au xxe siècle [Héritage et projet] (Montréal, 2007). 
In the initial stages of the redaction work, the lines were mostly set out by Giovanni Hoyois together with Pierre Bigo and Alfred de Soras of Action populaire. They found a significant source of inspiration in the 1958 campaign of Pax Christi on the topic of encountering cultures and people. ${ }^{33}$ In particular, the leaflets on culture's relation to civilization, the West, religion, and technique were seen as an "excellent starting point" for their doctrinal work. ${ }^{34}$ In fact the leaflets were seen as highly suited for a "codification." ${ }^{35}$ As a consequence, the author of the 1958 campaign, Bretaudeau, was invited to the first consultation on the topic in Louvain. In addition to him, Hoyois invited de Soras, Moeller, Dondeyne, and Leclercq. De Soras clearly advocated a limited notion of culture as those disciplines aimed at the development of natural values. This classical understanding was firmly linked to a preference for high culture. De Soras nonetheless admitted that broadening the notion to include the supernatural significance of culture for the human person in all its aspects was an option, ${ }^{36}$ but in that case examining culture would become the task of a sociologist. ${ }^{37}$ The latter three, professors at the Catholic University of Louvain, were in a position to help make the shift from social doctrine to personalism. They were all advocates of twentieth-century Christian humanism who aimed to renew faith and theology. In order to succeed, they looked at the opportunities offered by literature, existentialism, and sociology, respectively. In their work they had introduced a broad, anthropocentric understanding of culture as everything by which people realize and express themselves, including all that is done in light of their supernatural end. De Soras, for instance, explicitly pointed out that his position, in comparison to that of Dondeyne, was "desalinated."38 The integration of this personalist viewpoint was later strengthened when a fourth Louvain theologian, Jean Vieujean, also joined the project. He explicitly pled in favor of incorporating the notions of suffering and the cross in order to highlight the supernatural end of culture within a Christian humanistic worldview. ${ }^{39}$

The same tension became clear in the discussions surrounding the code's chapter on education. The first draft of this chapter was written by the Louvain professor of moral theology Jean Laloup, and was then submitted to Jean Vieu-

\footnotetext{
33 Rencontre des Cultures. Rencontre des hommes (Paris, 1958-1960).

34 Letter of G. Hoyois to A. de Soras, 11.05.1959, in F-Hoyois 833 .

35 Letter of A. de Soras to G. Hoyois, 8.05.1959, idem.

36 See esp. Letter of A. de Soras to G. Hoyois, o9.05.1959, idem.

37 Letter of A. de Soras to G. Hoyois, 29.12.1959, idem.

38 Letter of A. de Soras to G. Hoyois, 28.11.196o, idem.

39 Letter of J. Vieujean to G. Hoyois, 15.05.196o, in F-Hoyois 833 .
} 
jean and J.Van Camp. Particularly the latter emphasized the supernatural value of education and its preliminary role in establishing the human vocation. ${ }^{40}$ Moreover he situated the redaction of this chapter within discussions about an incarnational as compared to an eschatological approach, thus introducing a second tension that was central in the development of Christian humanism. Emphasizing that culture was not at all an absolute value, he warned against a two-realm theory in understanding the relation of the natural and the supernatural. ${ }^{41}$ Jean Vieujean's reflections on this draft went along the same lines; he mostly argued for the use of more general principles, instead of case-studies, which he felt were too concrete. In sum, he pled in favor of a text more suited to a moral code. As he expressed it, "There are certainly elements to be retained. But they should be written in a more 'conciliar,' more timeless, and sometimes less local (Belgian) style." ${ }^{22}$ To comply with everyone's wishes, it was eventually decided to add a preliminary chapter to the moral code, defining its basic concepts. In particular, the clarification of terms such as 'cultural action,' 'religious culture,' and 'supernatural action' were intended to alleviate ambiguity concerning the use of the term 'culture' throughout the code and thus make it presentable to the members of the Union de Malines. As Hoyois remarked to de Soras, the Code de moral culturelle had to adopt a new understanding of culture:

I am not surprised by your comments on the definition of culture. We are currently tending to move beyond the framework drawn by traditional conceptions of French thought, and the broad sense accepted by the project will undoubtly surprise many people. But it seems that this notion alone takes sufficient account of the recent contribution of the human sciences, in particular psychology and sociology, which tend to explain the human being taking into account the whole context, human and other, in which he is integrated, and in which he is deeply rooted,

40 This was also a topic to which Van Camp would return in his commentary on Gravissimum educationis, the conciliar declaration on Christian education. J. Van Camp, "La déclaration conciliaire sur l'éducation chrétienne," Humanités Chrétiennes 9, no. 5 (1966), 1-14.

41 On the integration of the natural and the supernatural in twentieth-century theology, see especially John Milbank, The Suspended Middle: Henri de Lubac and the Debate concerning the Supernatural (Grand Rapids, MI, 2005). The reception of this debate in the nouvelle théologie is best elaborated by Hans Boersma, Nouvelle Théologie and Sacramental Ontology: A Return to Mystery (Oxford, 2009).

42 "Il y a sûrement là pas mal de choses à retenir. Mais elles devraient être rédigées en un style plus 'conciliaire', plus intemporel et parfois moins local (belge)," in Letter of J. Vieujean to G. Hoyois, o9.06.196o, in F-Hoyois 833 . 
both consciously and unconsciously. It appears that Catholic sociologists are adopting this point of view, and not only the Americans, but now also others, including [members of the] Gregorian University. ${ }^{43}$

In 1961, the time was considered right to convene a new session of the Union de Malines in order to discuss the state of the moral code. However, of the around 60 members, only seven were ultimately able to attend the session. This limited commitment was, as Hoyois observed, the difficulty that had been faced in drafting the moral code. The second difficulty, and the greatest challenge in the redaction according to Hoyois, was the underlying debate about the notion of culture as it was used in the moral code. The result of this debate was not to choose for one or the other, be it the limited, classical idea of culture or the broader understanding, but rather to integrate them in one synthesis. ${ }^{44}$

Three years later, at the 1964 sessions of the Union de Malines, the drafting of the moral code had advanced well. The text had been reworked by external experts and by members of the Union. ${ }^{45}$ It was noted that the redaction was "sufficiently concise, and approached the style of a juridical code."46 Indeed, divided over four chapters, the code defined the most pressing issues of modern culture. The first chapter, which dealt with the basic notions of culture, was a novelty in the Union's tradition. This chapter afforded the opportunity to introduce the code's understanding of human nature and culture, the latter in its different aspects, social meaning, and diversified expressions. These descriptions emphasized the human person, human dignity, and the idea of

43 'Vos remarques sur la définition de la culture ne m' étonnent nullement. On tend actuellement à sortir du cadre tracé par les conceptions traditionnelles de la pensée française et le sens large qu' admet le projet étonnera sans doute plus d'un esprit. Mais il semble que cette notion soit seule à tenir compte suffisamment de l'apport récent des sciences humaines, en particulier de la psychologie et de la sociologie, qui tendent à expliquer l'homme par l'ensemble du milieu, humain et autre, dans lequel il est intégré, par ses racines profondes, conscientes et inconscientes. Je m' aperçois que les sociologiques catholiques, à commencer par les américains, mais maintenant aussi les autres, jusqu'à l' Université Grégorienne adoptent ce point de vue," in Letter of G. Hoyois to A. de Soras, 21.12.196o, F-Hoyois 833 .

44 "Le sens large, celui des sociologues, et le sens restreint, plutôt traditionnel, présentent chacun leurs avantages et gardent leur raison d'être. En conclusion, il est admis que l' ouvrage les exposera l'une et l' autre et s' efforcera de faire une synthèse des deux acceptions, de manière à pouvoir introduire valablement à l'ensemble des secteurs d' application ou se posent, en fait de culture humaine, des questions morales," Compte rendu 1961, in F-Hoyois 799 .

45 Among the members of the Union, it was particularly Czeslaw Strzeszewski who contributed in this phase; for the non-members, it was Russo, Heylen, and Géraud.

46 Compte-rendu 1964, in F-Hoyois 800. 
socialization. The second chapter provided a deeper analysis of physical culture, intellectual development, science, beauty, and religion and culture. The third chapter engaged with the promotion of culture through education, information diffusion via new media, as well as through work, technique, and leisure time. The last chapter addressed the social meaning of culture with elaborations devoted to the encounter between diverse cultures, as well as to the social environment, the family, the state, internationalization, and the Church. In a sense, this last chapter was a response to twentieth-century internationalism. ${ }^{47}$ In sum, the concept of culture, as it was used in this volume, could be defined in the following way: "Because it takes human development, i.e. the realization of human nature's potential, as its formal object, culture is fundamentally human." ${ }^{48}$

\section{The Conciliar Influence: From a Juridical to a Humanistic Style}

In the spring of 1964, Hoyois submitted his first suggestions to the bishop of Namur André-Marie Charue concerning the Second Vatican Council's Schema XIII on the Church in the modern world. ${ }^{49}$ In the following months, Hoyois would become one of this bishop's most frequent advisors; certainly that was true for the chapter on culture, over the redaction of which Charue presided. In the end, it would be precisely this chapter that was deeply marked by the humanistic renewal of the council. ${ }^{50}$ At the same time, this chapter on culture, embedded in Gaudium et spes, was also deeply marked by what O'Malley has called the pastoral shift towards a humanistic style on the part of the

47 This effort on the part of the Union de Malines to address internationalism proceeded from both religious and socio-cultural motives.

48 "Ayant formellement pour objet un développement de l'homme, une mise en valeur des virtualités de sa nature, la culture est essentiellement humaniste," in Projet de code de morale culturelle, 1964, in F-Moeller 1556.

49 Letter of G. Hoyois to A.-M. Charue, 10.08.1964, in F-Charue, see Leo Declerck, Inven-

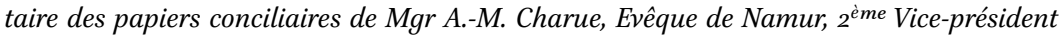
de la Commission doctrinale [Instrumenta Theologica, 40] (Leuven, 2017), 135; Letter of A. Glorieux to A.-M. Charue, 7.12.1964, idem. On Charue's efforts to involve Hoyois in the redaction of this chapter, see Charue's diary: Leo Declerck and Claude Soetens, eds., Carnets conciliaires de l'évêque de Namur A.-M. Charue [Cahiers de la Revue Théologique de Louvain] (Louvain-la-Neuve, 200o), 225-226; 228.

50 The council's humanistic revision of this chapter is well presented by Angelo Bianchi, "Introduzione: Il Concilio Vaticano II, la cultura contemporanea e gli studi umanistici," in Il Concilio Vaticano II crocevia dell'umanesimo contemporaneo, ed. Angelo Bianchi (Milan, 2015), vii-xvii. 
Second Vatican Council. ${ }^{51}$ Given that this shift was only something that happened at the council itself, the Code de morale culturelle had to be adjusted in accordance with the conciliar developments. At different stages, it became clear that the Union de Malines had partly prepared the path for the Pastoral Constitution, but the Union could not sufficiently adjust its own course in keeping with the far-reaching results established in Gaudium et spes. The tension between the work of the Union de Malines and the council can be perceived by examining the influence of the moral code on the redaction of Gaudium et spes and the difficulty of publishing the moral code after the council.

That Charue would appeal to Hoyois is no surprise. Just as it had not been foreseen that the Second Vatican Council would deal with the relation of the Church with the modern world, the theme of culture had also been largely absent up to the moment Cardinal Leo-Joseph Suenens launched the idea to deal with the Church ad extra on December 4, 1962. ${ }^{52}$ Although Suenens was the nominal president of the Union de Malines, he never made an effort to connect the redaction of the schema for which he was responsible with the work of the Union de Malines. ${ }^{53}$ The integration of the Union's work with the chapter on culture in Gaudium et spes was in fact mostly due to Charue. In the spring of 1963, when a first draft of the chapter on culture was being developed, Charue was added to this subcommission, and during the second intersession, he was appointed to temporarily preside over it. At the same time, he started to seek the advice of Hoyois on the topic. The latter provided Charue with some general remarks on the schema and some specific suggestions for the third chapter on culture..$^{54}$ By the end of 1964, the chapter still needed some "major overhauls" according to Hoyois. ${ }^{55}$ Around the same time, Charue informed those responsible for schema XIII that the moral code produced by the Union de Malines

$5^{1}$ John W. O'Malley, "Vatican II: Did Anything Happen?," in Vatican II:Did Anything Happen?, ed. David G. Schultenover (New York, 2008), 52-91; John W. O'Malley, "Il Vaticano II: Un Concilio umanistico," in Il concilio Vaticano II (see above, n. 50), 3-14.

$5^{2}$ For the most extensive overview of the council's treatment of this topic, see the excellent Giovanni Turbanti, Un concilio per il mondo moderno: La redazione della constituzione pastorale Gaudium et spes del Vaticano II [Istituto per le scienze religiose di Bologna: Testi e ricerche di scienze religiose: Nuova Serie] (Bologna, 200o).

53 In fact, only at the beginning of the fourth conciliar period did Hoyois submit a number of amendments to Schema XIII, but it seems that Suenens did not make any further use of them. Letter of G. Hoyois to L.-J. Suenens, 07.09.1965, in Fonds conciliaire de Suenens 2476. The conciliar archives of Cardinal Suenens (hereafter F-Conc. Suenens) are kept at the Archive of the Archdiocese of Malines-Bruxelles, Wollemarkt 15, Malines, Belgium.

54 Schéma XIII + Annexe III. F-Charue, 138.

55 "L' annexe III: 'de culturae progressu' semble appeler, par contre, d' assez sérieux remaniements," in Letter of G. Hoyois to A.-M. Charue, 10.08.1964, F-Hoyois, 891. 
could be of assistance in their redactional work, even expressing regret that the work of this organization had not been taken into account previously. ${ }^{56}$

A double strategy was employed. On the one hand, Charue intervened to have Hoyois sending a copy of the Code de morale culturelle to Achille Glorieux, secretary of the Mixed Commission together with Sebastian Tromp. ${ }^{57}$ Hoyois only met with the demand at the end of January $1965 .{ }^{58}$ On the other hand, an attempt was made to foreground the ideas of the Union de Malines. On the personal level, Charue informed Glorieux that the Jesuits Coffey and Russo were both members of the Union and could be involved in the work of redaction to a greater extent. At the same time, he requested that Hoyois be appointed a peritus. ${ }^{59}$ Although that request was not honored (in fact it was only Charue's other recommendation of Dondeyne as a possible peritus that was granted), Charue continued to support tying together the work of the Union de Malines and the subcommission on culture. This attempt was exemplified not only by Charue's invitation to Hoyois to be present at a meeting on January 20, 1965 with Dondeyne, Moeller, Etienne, and Ladrière, ${ }^{60}$ but also by Charue's mediating role between Hoyois and the editor-in-chief of La Civiltà Cattolica Roberto Tucci, who was one of the other important figures for the chapter on culture. On a more textual level, Hoyois too remained active by providing amendments to the chapter. ${ }^{61}$ It seems, however, that the work of the Union de Malines was not able to surpass the influence it achieved with Charue, for no other trace of their work can be found in the archives of the other central players in the redaction of Gaudium et spes, Pierre Haubtmann, Gerard Philips, and Charles Moeller.

The difficulty that the Union de Malines faced in disseminating its ideas must be understood on a different level than merely the one of lacking the right connections. It is much more the case that the concept of culture as presented

56 Letter of A.-M. Charue to G. Hoyois, 10.12.1964, in F-Hoyois 891; Letter of A.-M. Charue to A. Glorieux, 26.12.1964, in Archivio del Concilio Vaticano II (hereafter F-ACVII), 119o.367. The Archivio del Concilio Vaticano II is kept at the Archivio Secreto Vaticano, Cortile del Belvedere, Città del Vaticano.

57 Letter of A. Glorieux to A.-M. Charue, 07.12.1964, F-Charue, 165; Letter of A.-M. Charue to G. Hoyois, 10.12.1964, idem.

$5^{8}$ Letter of G. Hoyois to A. Charue, 15.01.1965, in F-Hoyois 891; Letter of G. Hoyois to A.M. Charue, 16.01.1965, in F-Charue, 166; Letter of G. Hoyois to A.-M. Charue, 28.01.1965, F-Charue, 172; Letter of G. Hoyois to A.-M. Charue, 03.02.1965, idem.

59 Letter of A.-M. Charue to A. Glorieux, 26.12.1964, F-Charue, 166.

6o Declerck and Soetens, Carnets conciliaires de l'évêque de Namur A.-M. Charue (see above, n. 49), 226.

61 Letter of G. Hoyois to A.-M. Charue, o8.09.1965, F-Charue, 174; Letter of G. Hoyois to B. Alfrink, o8.09.1965, F-Hoyois 891. 
by the Union de Malines was no longer suitable for integration into the future Pastoral Constitution. Indeed during the council, the drafters of this schema had to deal with major shifts: On the one hand, the redaction had been significantly influenced by external factors such as the promulgation of the encyclical Pacem in terris or the success of John Robinson's Honest to God. ${ }^{62}$ The success of both texts in reaching out to a broad audience showed that the classical doctrinal style used by councils would not appeal to a contemporaneous readership. On the other hand, the novelty of addressing the Church's presence in the world as a conciliar topic gave the drafters the opportunity to adopt a new style of writing. This difficult process in fact happened at a record pace. During the three-year drafting process $\left(1963^{-1965)}\right.$, the redactors went from a dogmatic text, to a sociological text, and finally to a Pastoral Constitution with what O'Malley has described as a humanistic style. Texts were repeatedly rewritten entirely, and redaction commissions were recomposed to ensure the best possible style. ${ }^{63} \mathrm{~A}$ rather fixed organization with yearly meetings such as the Union de Malines could hardly keep up with such a process.

This inability became clear at the Union's yearly meeting of 1965, which was a turning point in the redaction of the Code de morale culturelle. To start with, Russo and Coffey were in charge of reviewing the entire draft of the moral code. In the remarks of the first, it became clear that the progress of the council called for a rapid publication of the code. ${ }^{64} \mathrm{Next}$, the decision was made to change the name of the Code de morale culturelle to La culture et l'homme. ${ }^{65}$ This decision was simultaneously an effort to highlight the project's continuity with the previous work of the Union de Malines, as well as an effort to align the document's name more closely with contemporaneous interests. Indeed, when in the end the Union failed to publish the code before the end of the council, a process was initiated to revise the code according to the chapter on culture in Gaudium et spes. For this task, Hoyois approached Heylen precisely because he had earned his stripes in the conciliar redaction process. Heylen, however, referred Hoyois to Dondeyne, who according to him, was "the man" with the

62 John Arthur Thomas Robinson, Honest to God (Philadelphia, 1963).

63 Illustrative of the important role style played in the allocation of responsibilities is Gerard Philips's rejection in November 1964 of an invitation to act as coordinator of the redaction process. His stated reason was not being able to use the right style. See especially Yves Congar's description of this episode in Yves Congar, Mon journal du concile, 2 vols. (Paris, 2002), 2:275.

64 See esp. Letter of F. Russo to G. Hoyois, 18.01.1965, in F-Hoyois 833 .

65 See esp. Hoyois's contact with publishers: e.g. Letter of G. Hoyois to G. de Halleux, 01.07.1965, in F-Hoyois 833; Letter of G. Hoyois to J. Mahuzier, 15.03.1966, idem. 
competence to revise this code on culture. ${ }^{66}$ Charue had already said as much to Hoyois in February 1965, pointing out that the role of Dondeyne in the crucial Ariccia meetings of the conciliar subcommissions had been "primordial." 67 This recourse to Dondeyne ironically brought the redaction process back to the decision taken at the 1961 session to integrate two perspectives on culture into a single moral code: the dogmatic perspective represented by Action populaire, and the sociological perspective represented by Dondeyne. The fundamental contribution of Dondeyne to the conciliar chapter on culture had made him an authority for the post-conciliar time, when the standards for moral theology would be set by this conciliar document.

The discrepancy in content and style between the conciliar theology and the moral code would not prove to be the last hurdle for the Union de Malines. Although the first amendments for the revision of the moral code had already been drafted in August 1965, ${ }^{68}$ while the council was still ongoing, the moral code would not be finished before the closing session of the council, nor would it be finished thereafter. The publishing process proved to be a deathblow to the moral code, for three reasons. First of all, the Union de Malines had to search for a new publishing house to continue its series of codes. This was, on the one hand, the result of the split between the publishing house Spes and Action populaire. On the other hand, the idea of using another publishing house for this volume was also suggested by Russo, who wanted to reach a larger audience. Secondly, in their search for a more academic publishing house, be it the French Editions Universitaires, Desclée de Brouwer, or Casterman, it became clear that these publishing houses were rather hesitant to engage in this endeavor. The Editions Universitaires, for example, seriously doubted their regular customers would be "sufficiently interested," to enable the sale of at least half of the copies in their own book shops. ${ }^{69}$ In the end, Desclée de Brouwer proved to be the most viable option for getting the manuscript published, but only if the Union de Malines was willing to oversee the printing costs. ${ }^{70}$ The ultimate failure of the project, however, is attributable to the Union de Malines itself. Despite Ho-

66 "C' est l'homme," in Letter of G. Hoyois to V. Heylen, 20.06.1966, in F-Hoyois 833; Letter of V. Heylen to G. Hoyois, 21.o6.1966, idem.

67 Letter of A.-M. Charue to G. Hoyois, 07.02.1965, in F-Hoyois 891.

68 Amendements proposes pour mieux harmoniser le projet de Code de morale culturelle avec le projet de schéma conciliaire 'de culturae progressu', 31.08.1965, in F-Hoyois 801.

69 "Il me parait très difficile que nous pouissions éditer ce volume. [...] Je doute que le public des librairies, qui est le nôtre, s' intéresse suffisamment à cet ouvrage pour nous acheter dison la moitié du tirage durant la première année suivant la parution," in Letter of J.P. Delarge to G. Hoyois 15.03.1965, in F-Hoyois 833 . Letter of J. Mahuzier to G. Hoyois, 10.09.1965, in F-Hoyois 833. 
yois's promises that the manuscript would be fine-tuned to bring it more in line with the Pastoral Constitution, the final revised version was never completed and never delivered to the publisher. ${ }^{71}$ Despite the "urgency"72 of this publication on account of the many commentaries on Gaudium et spes published in the same period, the work of the Union de Malines was never realized.

\section{Conclusion}

In his overview of the development of natural law theory in Catholic Social Teaching, Stephen J. Pope pointed out "the fundamental transformation of the character of Catholic social teachings that took place at the time [of the council]." ${ }^{\prime 3}$ This transformation, according to him, found expression in four important features: the recognition of the modern world, the affirmation of the historical context and development, a Christological ressourcement, and a renewed appreciation of human dignity. These features were certainly reflected in Gaudium et spes, which, with its central notion of reading the signs of the times (Gaudium et spes 4), would become the cornerstone of later Catholic moral theology. The council's transformation of the grand tradition of Catholic Social Teaching had a strong impact on the plurality of little traditions. A wellembedded tradition, such as the Union de Malines with its moral codes, could either incorporate the new conciliar perspectives on social ethics or cease to exist. The latter proved to be the case for the Union de Malines. This result, however, was not only due to the transformation of Catholic Social Teaching as an internal development of the Roman Catholic Church. It likewise resulted from the transformation of society, to which the council was able to respond more deeply than could be accomplished by the prescribed format of the moral codes that the Union de Malines produced. The possibilities for responding to these ecclesial and societal transformations were, moreover, limited. Particularly the rigid structures of the Union de Malines as an organization with yearly meetings and a relatively uninvolved membership could not catch up with a conciliar process led by highly motivated council fathers and theologians. In

71 Letter of G. Hoyois to the publishing house Desclée de Brouwer, o7.03.1966, in F-Hoyois 833; Letter of J. Mahuzier to G. Hoyois, 15.o3.1966, idem; Letter of G. Hoyois to J. Delfosse, o9.05.1966, idem; Letter of L. Van Weyenbergh to G. Hoyois 13.07.1966, idem.

72 Letter of G. Hoyois to De Potter (Desclée de Brouwer), 10.08.1965, in F-Hoyois 833 .

73 Stephen J. Pope, "Natural Law in Catholic Social Teachings," in Modern Catholic Social Teaching. Commentaries and Interpretations, ed. Kenneth R. Himes (Washington D.C., 2005), 41-71, there 53 . 
sum, moral theology and culture were not so much questioned by the work of the Union de Malines from 1956 onwards, as this organization was questioned by a development that took place in both spheres: the societal as well as ecclesial shift from hegemony to diversity, from social doctrine to personalism, and from a juridical to a humanistic style. Although efforts were made to integrate the first two developments into the work of the Union de Malines, the latter development would in the end render that work obsolete.

The failure of the Union de Malines to adapt its moral tradition to the times has a threefold significance. First of all, it is a sign that the late 195os and the beginning of the 196os were aptly described by Chenu as the end of an era. The ideas, methods, and style applied by the Union de Malines were formed by and well-established in the moral traditions of mass-Catholicism, with neoscholasticism as its theological form of expression. These traditions could to a certain extent contribute to the rise of other understandings and traditions within Catholicism, such as the influence that Left Catholicism would exert on moral theology, but they could not be entirely transformed. At the same time, the cultural developments of the 1950s and 1960s could be properly described in this tradition. Indeed, as David Hollenbach pointed out "cultural pluralism and social conflict were more adequate descriptions of the context of the Church's social mission at the time of the council than the organic model of society assumed by neoscholasticism." ${ }^{74}$

The importance of culture both as an autonomous realm with its own development to which the Union de Malines sought to respond, and as a notion that the Union treated theologically in its moral codes cannot be overestimated. The same notion became, not without reason, one of the stumbling blocks for later currents of theological thought such as Radical Orthodoxy in its evaluation - and occasional critique - of the Second Vatican Council's relation to modernity. Interestingly enough, while pointing out that "although the authors of Gaudium et spes acknowledged that the concept of 'culture' is multifaceted, they nonetheless failed to identify precisely what they meant with each usage of the term,"75 Tracey Rowland mentions only Albert Dondeyne by name. Whereas in the 196os it was precisely this theologian who was considered better equipped than the moral tradition of the Union de Malines to satisfactorily describe culture within a moral-theological setting, the theological difficulties are now partly attributed to him. Both the drafting of the Union's moral code and its relation to Gaudium et spes do, however, show that the notion of culture

74 David Hollenbach, "Commentary on Gaudium et spes," in Modern Catholic Social Teaching (see above, n. 73), 266-291, there 277.

75 Rowlands, Culture and the Thomist Tradition After Vatican II (see above, n. 10), 20. 
and the development of Catholic Social Teaching were still very much under discussion at the time; the authors of both documents were fully aware of the transitional and contextual nature of their work.

The present article has affirmed Jean-Yves Calvez's observation that "Vatican II brought quite a change in the style of expressing the social tenets of Christianity."76 More than that, however, we have observed that the little social traditions of the Catholic Church have their own development, which is nevertheless interconnected with this grand tradition. On the one hand, despite being little, traditions such as the Union de Malines contributed to the development of moral theology on an intellectual level by the publication of their moral codes, but also on an organizational level by establishing networks and creating platforms by which theologians could diffuse their ideas. As such the little traditions were able to contribute, by providing ideas and authors, to the grand tradition at epochal moments, such as the Second Vatican Council. On the other hand, these little traditions were also highly dependent on this grand tradition and became vulnerable the moment a certain theological tradition was adopted as more authoritative than others, whether that tradition is NeoScholasticism or the pastoral theology of the Second Vatican Council. This case study of the Union de Malines points out that despite their interconnectedness both the grand tradition and the little social traditions followed their own pace, all contributing to theological renewal and paradigm shifts. As such they bore witness to the legitimacy of theological diversity that was heralded by Chenu in his programmatic article, affirmed in the conciliar documents, but questioned in the post-conciliar era.

76 Jean-Yves Calvez, "Things Old and New: Catholic Social Thought in Retrospect and Prospect," in Catholic Social Thought (see above, n. 6), 3-11 at 6. 